\title{
Who will exploit academic ideas?
}

\section{The wheel has come full circle in Britain, where the government is about to remove a monopoly on public innovations. Universities hope to benefit. They may not.}

IMMEDIATELY after the Second World War, the then British Government was persuaded (chiefly by the late Lord Blackett) that steps should be taken to make fuller use of British inventions. The result was an organization called the National Research and Development Corporation (NRDC), a publicly-supported entrepreneur given a first option on the exploitation of innovations arising from the use of public funds. Last week (see Nature 15 September, p.172) Mrs Margaret Thatcher, the Prime Minister, reminded her special seminar on technology and "wealth creation" that too many British innovations were being exploited by other nations - and then announced that NRDC would lose its right of first refusal. The objective now, as in 1947, is to wring more benefit from home-grown inventions. What has changed - or gone wrong? The question is important not merely for British taxpayers but for most other industrial states looking for more prosperity from innovation.

Those most directly affected by the government's decision, NRDC itself and the rump of the old National Enterprise Board with which it is now united in the British Technology Group (BTG), will probably be relieved by Mrs Thatcher's announcement. The threat that something like this was about to happen has been public knowledge for nearly two years. For much of that time, inventors have been puzzled to know what they should do with their bright ideas, a recipe for neglecting them. In practice, last week's decision will be widely, even enthusiastically, welcomed. But there is a danger that people - inventors and the government - will now expect too much. It is far from clear that NRDC's difficulties can be avoided by others.

NRDC has been through several cycles of up and down, but outwardly it has always been a profitable organization. The principle was that the government (at first the Treasury, more recently the Department of Industry) would provide a stock of capital, that NRDC would sift through all the bright ideas within its purview, take out patents on those that looked promising and carry them through to the marketplace by investing (sometimes in partnership with others) in their development. While in principle the public capital ( $£ 50$ million at its peak) was always totally at risk, NRDC has been lucky always to have had a money-spinner on its books. At the outset the wartime Bailey bridge helped to balance the books. Since 1960, the cephalosporin antibiotics have taken over that role. In its time NRDC has also backed several conspicuous failures - hovercraft, linear motors for train propulsion, fuel cells that were overtaken by events and the "Dracone" (a way of transporting petroleum by sea in a huge sausage pulled by tugs). Such are not, however, the reasons why NRDC has become unpopular. It has been forgiven its errors of commission, but its inclination to say no has made it an army of enemies.

Not all that criticism can be sustained. Like those who write books, inventors often have a keener appreciation of the merits of their works than of their defects. They naturally visit their wrath on those who decline to back financially what they have done. There is no proof that NRDC was ever inconsistent in its judgements. What is clear, however, is that NRDC was often slow to take a bright idea onto its books and that, when it had done so, it would fail to give the originator of the project a good reason for skimping on development costs.

The underlying difficulty, for everybody concerned, is that the scale of NRDC's operations was always in principle arbitrary - at any stage it could have been investing at twice or half the going rate without knowing which course would in the long run be more profitable. So, in practice, it played safe, and lived within its assured income, hoping never to be accused of gambling unsuccessfully with public funds. NRDC's monopoly right has been in jeopardy at least since the occasion a few years ago when the Medical Research Council successfully argued for a waiver from the government that allowed it to sign a first refusal deal with Celltech, the then new biotechnology company. What the government now intends is that NRDC should stay in business (within BTG) but compete with other entrepreneurs (all private) for patentable inventions to back. British universities and academics are looking forward to being rich. But they are likely to be disappointed.

Even so, the decision to end the monopoly is right. When there were virtually no sources of funds (venture capital is the usual term), one was plainly better than none. In the present circumstances, with merchant banks and ad hoc venture funds prowling around universities and other public places, the monopoly is an anachronism. The essence of the relationship between an innovator and his backer is that the backer should share some of the enthusiasm of the inventor, should nevertheless have a capacity to decide quickly (if wrongly) when a project has gone wrong, and should be willing to go on his hands and knees to others for extra capital if (the rule, not the exception) a development project remains promising but costs more than originally foreseen. It is inappropriate that salaried public servants should attempt all these roles using public money. NRDC's record shows that it has not tried to do so vigorously, even if it can take credit for having heightened the interest of academics in innovation and its exploitation.

What will happen next is an open guess. To begin with, the universities will be most directly affected. Corporately, their difficulty will be to choose between activity (seeking out new ideas, even taking out patents) and passivity (letting academics who consider their work to be ripe for exploitation take the initiative. There are strong arguments against too much activity - it is distracting, expensive and there can be no assurance that universities will be more imaginative than NRDC. But passivity implies a return to the period before NRDC, although with the difference that there are more organizations willing to invest in novel projects. Perhaps that development is NRDC's most enduring success.

\section{Policy by merger}

\section{Taking scissors and paste to the US bureaucracy} is fashionable but could be dangerous.

THE Reagan Administration has a poor record on the reorganization of the federal bureaucracy. It came to power pledging to abolish the Departments of Education and Energy. Both, for different reasons, continue. Now attention in Congress is being transferred to a new administration proposal - merging the Commerce Department with the White House Office of the US Trade Representative in a new Department of International Trade and Industry. This idea, reflecting as it does the 